\title{
Circular Economy across Australia: Taking Stock of Progress and Lessons
}

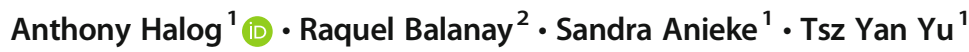 \\ Received: 7 February 2021 / Accepted: 25 February 2021 / Published online: 17 March 2021 \\ (C) Springer Nature Switzerland AG 2021
}

\begin{abstract}
Australia has intensified its circular economy (CE) efforts that demonstrate designing out waste while creating wealth. It has developed eco-industrial parks in metallurgy/metal industries, eco-cities and small-scale waste-to-wealth creation strategies. Mining has taken the lead in CE development with the eco-industrial areas at Kwinana, Western Australia, and Gladstone, Queensland. Easing up the waste burden, eco-efficiency and value addition are the direct benefits of circularizing the economy. Shortsightedness in looking up for opportunities across the supply chain, technological constraints, lack of policy coordination for business innovation, economic recession induced by the COVID19 pandemic and lack of incentives to change behavior from linear to circular economy are among the barriers pointed out. A systematic review of published literature in Australian context was conducted to assess the state-of-the art circular economy development. We have found that Australia has to look into overcoming the barriers by putting in place policies and guidelines to nurture the current synergies, business relationships and trust among the firms in partnership, and more $\mathrm{R} \& \mathrm{D}$ to meet the demand for complementing technologies and to have cohesion over the current CE strategies, among others.
\end{abstract}

Keywords Circular economy · Circularity · Eco-efficiency · Waste-to-wealth creation · Environmental footprints $\cdot$ Australia

\section{Introduction}

Circular economy (CE) as a comprehensive strategy for sustainable development has already spread throughout the world. More countries have come into its fold as innovations of diverse

Anthony Halog

a.halog@uq.edu.au

1 School of Earth and Environmental Sciences, The University of Queensland, Brisbane 4067, Australia

2 College of Agricultural Sciences and Natural Resources, Caraga State University, Ampayon, Butuan City, Philippines 
types have kept on coming and moving at a fast pace. It is noteworthy under this development that the global spread of CE is backed by support from multiple sectors. The business sector in particular has learned to get along and make proper adjustments in connection with CE principles the fact that potentials for economic benefits to be sustainable are possible with it. European countries have quite championed in demonstrating how these benefits could turn out to be as conceptualized, in which the contribution to the environment is hugely recognized. Australia as the sixth largest country in the world has caught up much in this endeavor with heightened activities of the business sector showing some seamless integration of $\mathrm{CE}$ into their business principles and strategic operations besides forging alliances for streamlined synergies.

With that, Australia can be said to have done a great deal of works resulting to the pervasive observance of CE especially across its major cities (e.g. Melbourne, Sydney and Brisbane) and this is further demonstrated as pointed out in the systematic review results below. The environmental outcomes and the change of outlook into the future with waste as a resource contribute largely to this context. Australia has turned specifically to look at the opportunities with its waste, charting the new directions of its businesses and the necessary adjustments that must be done to align the business strategies to the principles of circular economy. Similar with other countries, it has been attuned to the potential benefits of circular economy in terms of employment generation and market development from expanded value-adding activities. In all of these efforts, innovation is key, not only in developing products and in services but also in implementing mechanisms to integrate and carry out CE practices and/or activities perfectly (e.g. IT, social networks, NGOs and media). Technopreneurship and design-led innovations are quite relevant in this aspect to determine the various configurations of CE systems, which can deal with the technological and structural challenges in undertaking $\mathrm{CE}$ at the local, state, federal and global levels [1-4].

Across the Australian landscape, the drivers to go circular have gained ground with the increasing consciousness on the fundamental importance of environmental sustainability in uninterrupted growth. These may have come in different labels such as industrial ecology, green economy and the like but still the same in essence when put into action. The context of such is in fact enshrined in the report of Barlow [5] for Australia's opportunities in food and fiber industries where environmental health is emphasized. With climate change observable in the country, it is not farfetched for circularity to be mulled upon seriously as a quintessential strategy to put under control the footprints of industries across the country. This paper conducts a systematic review to know the state-of-the-art development in Australia including anecdotes on how the country comes to weave into its economic landscape the circularity initiatives to learn the benefits, gain lessons and make improvements from there. It highlights the sectors of the Australian economy, which has put circularity a serious business that proves to be working overtime. It accounts the mechanisms that have the revolutionizing potential for circular economy to be well-integrated in sectors and present the problems and lessons that pose challenges for Australia to make full the implementation of a circular economy.

\section{Methodology}

This paper employed the use of a systematic review to collect secondary data from scientific publications and academic literatures. The study collected data through a rigorous search and selection process from Scopus database. The first stage of data collection in the systematic 
review involved the identification of the appropriate criteria of inclusion for the study. The criteria of inclusion considered in this study include the year of publication, the geographical location, the keywords and language. Overall, only articles which cited Australia, were written in English and published from a timeline of 2014-2021 were selected. In addition, the keywords "circular economy", "recycling", "circularity" and "Australia" were considered for the study.

The second stage of the systematic review involved searching for articles. The keyword "circular economy in Australia" was searched for in the Scopus database. The search produced a total of 59 documents which was carefully scanned and evaluated for appropriateness and inclusion. The next stage involved careful examination of the articles to search for the right articles that fit into the scope of the study. After this stage, fourteen (14) articles were removed because they appeared to be irrelevant to the study leaving a final sample of forty-five (45) articles which were analyzed in the final stage of the systematic review.

\section{Results}

This section analyzed a final sample size of 45 articles taking into consideration: firstly, the distribution of articles per year of publication; secondly, the industry reference; and finally, the percentage of industry referenced under each year of publication. The result for the data collection and analysis is presented in Table 1. The table shows the number of articles selected following the year of publication and industry reference. The results will be further discussed in subsequent sections.

\section{Article Distribution Per Year of Publication}

The distribution of all 45 selected articles is illustrated in Fig. 1. The figure indicates that 2015 had no circular economy publication in Australia. It also highlights 2019 and 2020 as the year with the highest number of circular economy publications in the country. The increase in the number of publications in recent years goes further to prove that the country's interest in circular economy has intensified given that the concept is highly beneficial in all ramifications particularly in regard to waste reduction and management.

\section{Industry Reference}

Figure 2 illustrates the different industries cited for published circular economy studies in Australia. The wide range of papers presented in Table 1 and illustrated in Fig. 2 signified that different industries in Australia have adopted circular economy approaches in their processes. The metal industry (metallurgy) including its exploration, processing and manufacturing was the most cited industry among the selected publications. Another commonly cited industry after the metal industry is the electronic waste (E-waste) industry, which includes technological wastes like computers, television, smart phones, etc. The third group of industries frequently mentioned in the articles is urban planning and built environment. Several states around Australia are adopting a more circular approach in planning their cities to ensure a more sustainable and inhabitable environment.

Other range of industries referenced in the publications includes agriculture and food processing, construction, transportation, electricity as well as the education and research 
Table 1 Result for article distribution and industry reference cited in dataset of 45 papers

\begin{tabular}{ll}
\hline Article distribution per year of publication & No. of articles \\
\hline 2014 & 4 \\
2015 & 0 \\
2016 & 5 \\
2017 & 3 \\
2018 & 4 \\
2019 & 13 \\
2020 & 12 \\
2021 & 4 \\
Total & 45 \\
Industry reference & No. of articles \\
E-waste & 7 \\
Metallurgy & 9 \\
Urban planning & 6 \\
Mining & 3 \\
Agriculture and food processing & 5 \\
Construction & 4 \\
Academic and research & 4 \\
Transportation & 4 \\
Electricity (solar) & 2 \\
Others (glass, oil and S.M.E) & 2 \\
Total & 3 \\
\hline
\end{tabular}

industries. Australia's zest to transition from a linear economy to a more circular economy probably explains the reason for the heightened interest in circular economy across the wide range of industries in the country.

\section{Industry Reference Per Year of Publication}

Figure 3 illustrates the type and percentage of industries referenced under each year of publication using a stacked column graph. This figure shows that articles about the metal

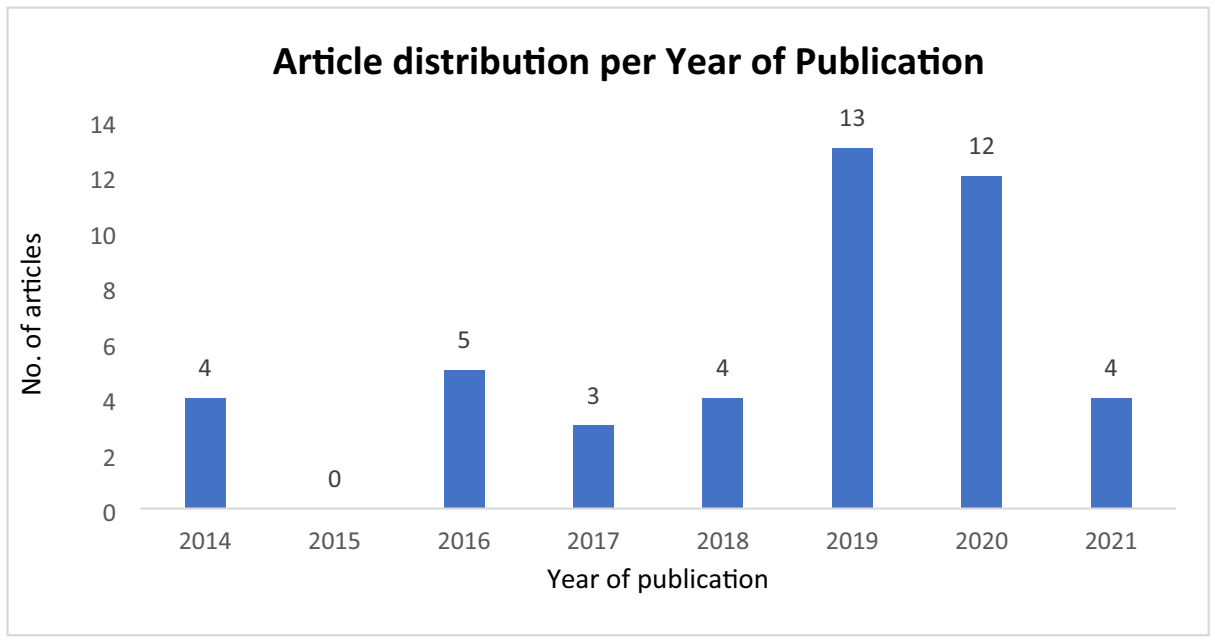

Fig. 1 Distribution of selected articles per year of publication 


\section{Industry Reference}

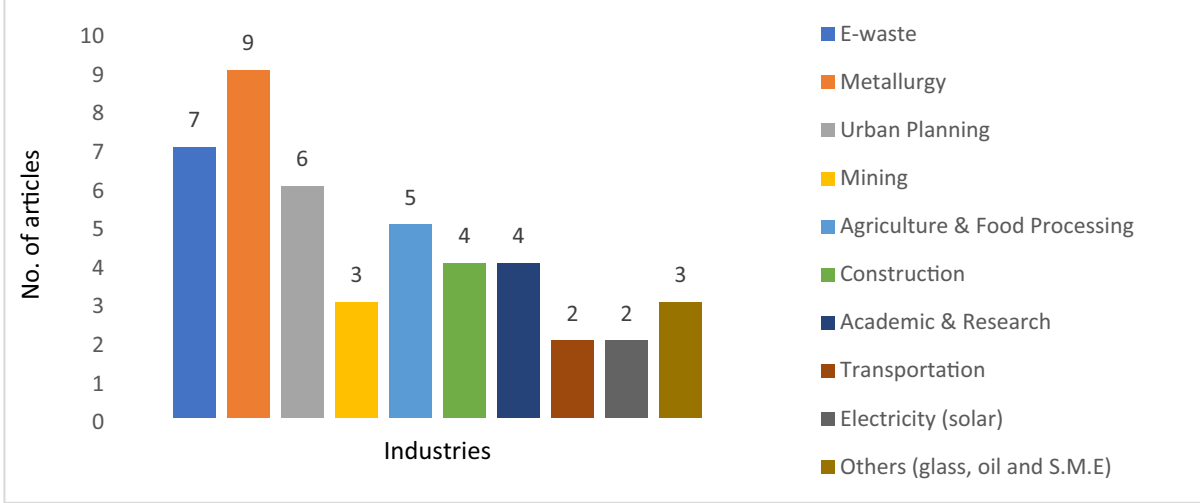

Fig. 2 Distribution of selected articles based on referenced industries

industry (presented in orange color) were published in for most of the years except in 2016. Similarly, the E-waste industry (presented in a blue color) has the second highest publication by years except in 2016 and 2021 where it had no publication.

Figure 3 also shows that 2019 and 2020 have the most range of represented industry references with 8 and 9 different types of industries represented respectively. 2014 has the least industry representation with the metal industry being the most cited in this year. Other industries like mining, construction and urban planning were evenly distributed across the years particularly from 2017 to 2021 . The academic and research sector has only recently begun to gain traction and develop interest in the subject area. The Australian Commonwealth Science and Research Organisation (CSIRO) is now partnering with universities and performing research on ways to adopt a circular economy methodology into various processes to ensure sustainable production and consumption.

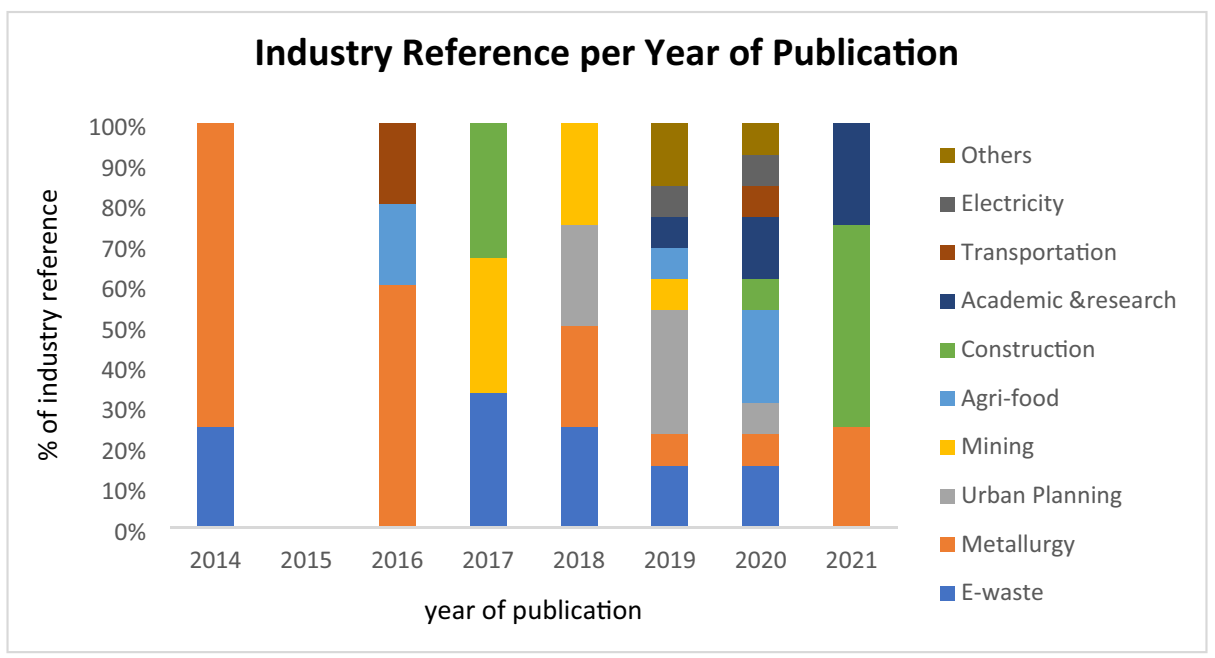

Fig. 3 Percentage of industries referenced in selected articles per year of publication 


\section{Discussion}

Across Australia, the rudiments of circular economy have been observed in many forms which include household collection and recycling of paper and plastic, infrastructural planning, levies on landfill waste disposal, metal recycling as well as regulations and legislations on wastes under the jurisdiction a state's environmental protection ACTS. Australia's transition towards circular economy is noted to be more conservative due to its smaller yet dispersed population and reliance on resource extraction through mining processes. In Europe and some parts of the world like China, circular economy transitions have gained huge traction and are widely adopted compared to Australia. Undoubtedly, circular economy in Australia is essential because it has its own environmental, societal and economic benefits. Klynveld Peat Marwick Goerdeler (KPMG) in 2020 estimated that by 2048, the potential present value of circular economy's contribution to Australia's GDP would grow up to $\$ 210$ billion approximately [6]. Despite this significant quota, a worldwide assessment on the progress of circular economy published in the Circularity Gap Report [7] indicates that only about $8.6 \%$ of the world is circular.

According to the Australian constitution, the state governments have the sole responsibility to handle issues regarding the environment. The policies and governance models developed by the states are crucial because of their connection with the environment and economic activities within the state or region. Different approaches are employed by various states; some of these approaches are similar to one another while others remain distinct. Overall, it is fair to say that some states emerge strategically more advanced than others in situations like this, due to the different stages of development and implementation. Furthermore, many states possess existing waste strategies and have further implemented operational schemes like South Australia in 1977, Northern territory in 2012, New South Wales in 2017, Queensland in 2018, Western Australia in 2018 and the Australian Capital Territory in 2020 respectively [8]. Other states like Tasmania announced its intention for a scheme in 2021 while Victoria remains the only state in Australia yet to make commitments to a scheme.

Like China's 2011 National Sword Policy, Australia is now conscious of many circular economy opportunities and benefits; hence, it recognizes the importance to develop new circular economy initiatives and responses both at the national and the state levels. One of those initiatives involves the updating of the National Waste Policy in 2018 which was previously implemented in 2009 by Australia's Department of Agriculture, Water and the Environment [9]. This policy provides the government, businesses, communities and individuals with a framework for collaboration up to 2030. Additionally, Australia's National Food Waste Strategy implemented in 2017 aims to reduce the country's food waste by half in 2030 through the establishment of an effective framework to support actions that accomplish the desired outcome [10]. These measures, such as food waste diversion from landfill, align with the SDG Goal 12 (to ensure sustainable/responsible production and consumption) through its support for global action to reduce food waste. Furthermore, the academic and research sectors on circular economy are not left out as several universities in Australia now place huge attention on sustainable practices, thus exploring ways to create more efficient materials and products. In recent times, research organizations like the Australian Commonwealth Science and Research Organisation (CSIRO) have commenced collaboration with universities to explore material flow analysis and models which would give a better comprehension of the country's current state of material flows compared to a scenario of enhanced circularity. 
On the industrial setting, Australia is one of the world's leading manufacturers due to its advanced and lucrative manufacturing industries, although it still relies greatly on agriculture, mining, forestry and exports [8]. Circular economy within the country is practiced among a wide range of industries ranging from agriculture, metallurgy, plastic, mining, construction to textile industries and many more. Several published studies particularly between 2014 and 2018 indicate that in fact a large proportion of Australia's circular economy practices is focused on metal reuse and recycling [11-13]. The desire to create high-performance alloys and technological solutions using processes and innovations that are sustainable explains why a vast number of circular economy publications in the country focus on the metallic industries. One example of such publication is Gumley's [14] article on the analysis of regulatory strategies for Australia's metal recycling and reuse. The author uses the concept of circular economy to review briefly the nature and trend of regulatory strategies as well as the application of the regulatory framework to the different stages of a metal's life cycle from mineral extraction, processing and conversion to finished products and final disposal.

Transitioning to a circular economy would require a significant change in behavior or habitual practices. For any behavior change program to be effectively designed, it is crucial to determine any potential barriers to the achievement of the desired goal. The Australian Circular Economy Hub [15] identified a number of barriers through research and feedback that may hinder Australia's circular economy transition. Some of these barriers include economic recession induced by the COVID-19 pandemic, lack of data accessibility and availability, regulations on alternative business models, data and information disparities, incomplete policy harmonization and framework, and lack of incentives or choice to change behavior from linear to circular. In light of the above, the Australian Circular Economy Hub [15] put forward a circular economy strategic action plan for 2020 to 2023 in order to facilitate the country's transition to a circular economy. These plans highlight four vital strategic pillars that include to inspire and amplify, to educate and connect, to support and promote and, finally, to enable action. While the first pillar drives circular economy awareness among businesses and the government, the second pillar seeks to build and share knowledge through encouraging collaboration. Simultaneously, the third pillar identifies and overcomes potential barriers to create favorable conditions while the final pillar facilitate and contribute to national initiatives that are highly impacted.

\section{Progress in Circular Economy: Sectors Involved and Eco-Industrial Parks}

Circularity is for closing the loops, which means keeping in check the externalities of industrial operations such as unwanted emissions to air, water and land. Australia's efforts towards it are noticed to have an expanding coverage across sectors.

\section{Large-Scale Initiatives (Multiple Industries)}

The Australian mining sector has done a great example to demonstrate strategies of circularity in operations. The sectors involved in this aspect had connected many firms in the aim of keeping the footprints under control. In doing so, industry partnerships and synergies had been developed to carry out the uptake and reuse of waste to create products and wealth. Australia as largely a mining country has provided an indulgence and great favor to the environment with a lot of mining wastes being reused in the process. A showcase of a mining-based industrial symbiosis had been created, which has exemplified the workings of an eco-industrial 
park or an efficient waste to wealth creation process incurring huge savings to the Australian firms involved [11, 16]. Van Beers et al. [17] had documented this aspect as regional synergies for the mining and mineral industry. These regional synergies are labeled so because industries' give-and-take relationships are not constrained by geographical boundaries. Such synergies have demonstrated the symbiotic exchanges between or among industries that lead to easing up the waste burden from mining or mineral processing. The arrangement of which and the critical roles of each industry are highlighted in Figs. 4 and 5, and Table 2. Golev et al. [16] had followed up on this for the case at Gladstone Industrial Park specifically.

Van Beers et al. [17] had described industrial symbiosis as a means of circularity for Gladstone, Queensland and Kwinana, Western Australia, with that of the latter as a bit mature and much more participated in than the other. Sustainable resource processing is at the forefront on the setup of this mining-based industrial symbiosis and eco-industrial park at Kwinana, Western Australia (Fig. 4). Figure 4 shows the heavy industries involved, which include an alumina refinery (Alcoa), a nickel refinery (Kwinana Nickel Refinery), a titanium dioxide pigment plant (Tiwest), lime and cement kilns (Cockburn Cement), an oil refinery (BP) and a pig iron plant (HIsmelt). As such, Kwinana is considered as a pillar of Western Australia's economy. Annually, it generates more than A $\$ 4.3$ billion in total output; by then, the entire eco-industrial area employed more than 3,600 workers (i.e. for core industries and other related firms) [17]. It has synergies built for both by-product and utilities (Fig. 5). Respectively, Figs. 4 and 5 show the specific by-product and utility exchanges among the firms involved at the Kwinana Industrial Area in Western Australia.

The Gladstone Industrial Park is another large-scale showcase of attempts towards circularity $[16,17]$. It consists of a huge area where big industries such as the Queensland Alumina Ltd (QAL), NRG Gladstone Power Station, Cement Australia Holdings Pty Ltd (Gladstone plant), Boyne Smelters Ltd, Orica Yarwun, Rio Tinto Alcan Yarwun and Queensland Energy Resources Ltd operate with the aim to control the footprints of their operations by reusing some wastes. All of these corporate organizations have large-scale operations wherein their

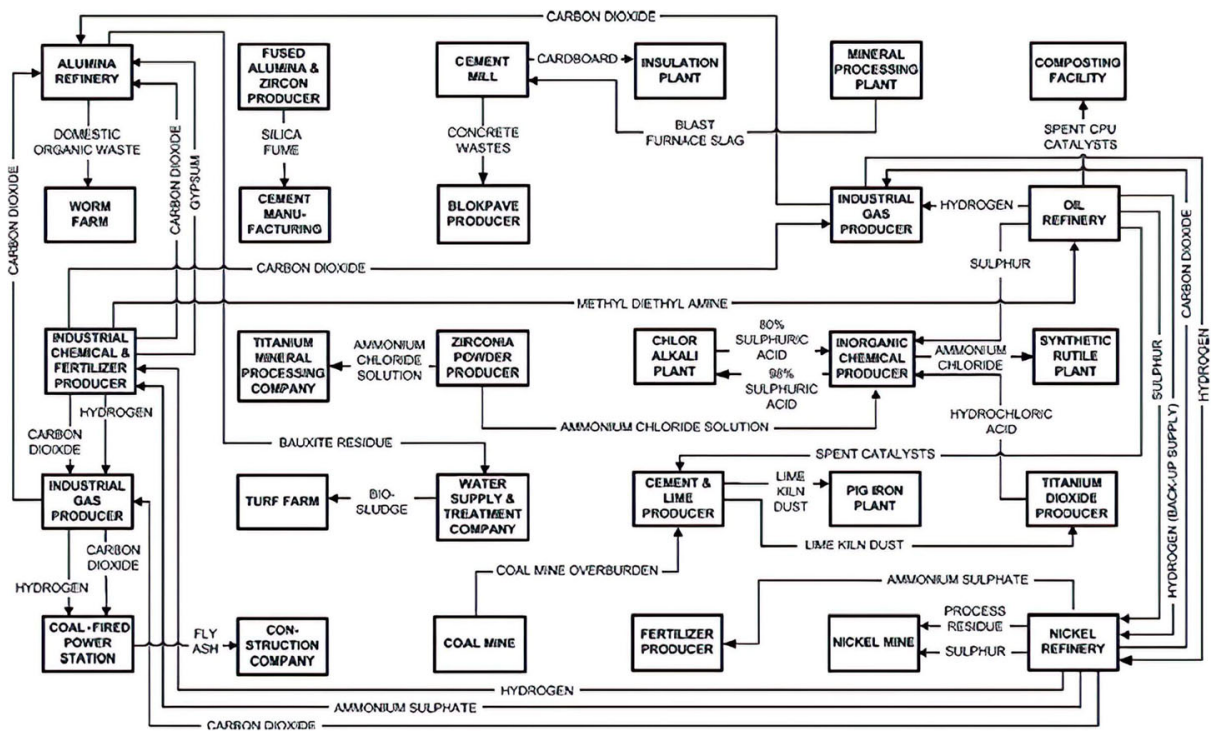

Fig. 4 The Kwinana Industrial Park's by-product synergies [17] 


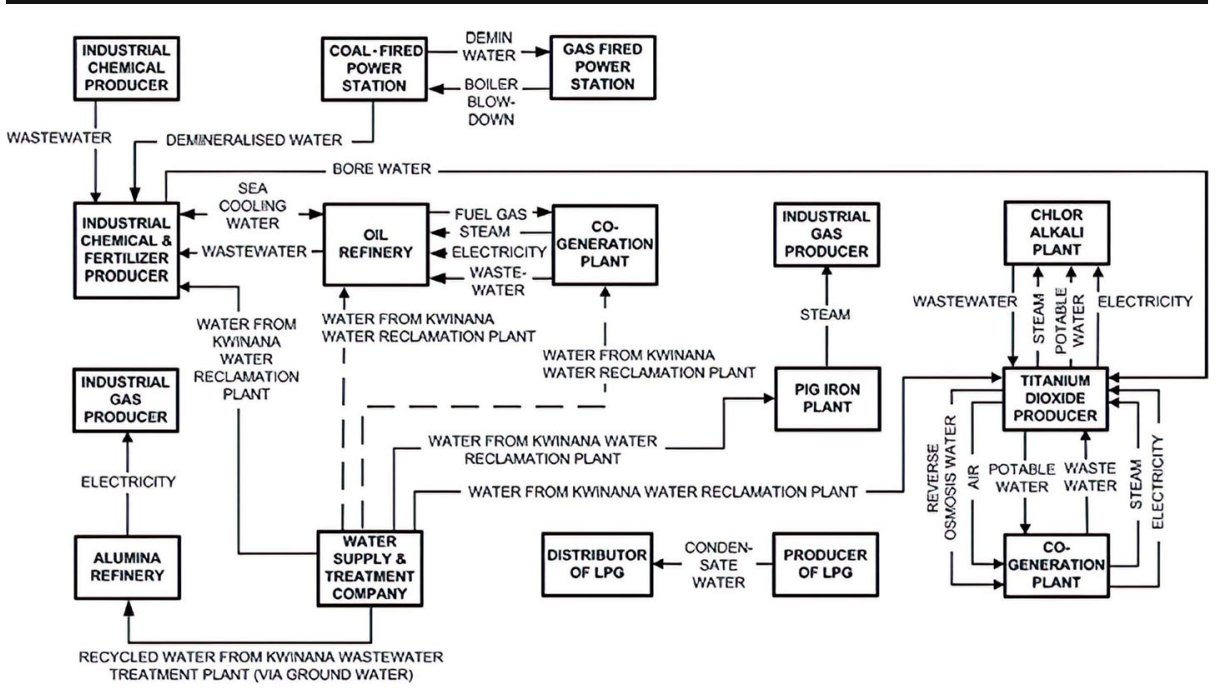

Fig. 5 The Kwinana Industrial Park's excess energy-based synergies [17]

efforts with respect to their size to reuse waste become significant enough to be exemplified in this work. Table 2 describes the specific synergies that help control the wastes of the firms in the Gladstone area through symbiotic relationships. The potential synergies convey the

Table 2 The synergies for circularity in the Gladstone Industrial Park [16]

\begin{tabular}{|c|c|c|c|}
\hline Waste & Generated by & Reused by & Benefits \\
\hline $\begin{array}{l}\text { Secondary treated water } \\
\text { effluent }\end{array}$ & $\begin{array}{l}\text { City's sewage } \\
\text { treatment plant } \\
\text { (STP) }\end{array}$ & $\begin{array}{l}\text { NRG Gladstone } \\
\text { power station, } \\
\text { Queensland } \\
\text { Alumina Ltd }\end{array}$ & $\begin{array}{l}\text { The synergy resulted to the } \\
\text { establishment of an } 8.5-\mathrm{km} \text { pipeline } \\
\text { from the Calliope River STP to } \\
\text { QAL. The water effluents are } \\
\text { reused in the red mud washing } \\
\text { operations to substitute fresh water } \\
\text { supply from Awoonga Dam. } \\
\text { The total quantity of the reused } \\
\text { water is estimated at about } 2.6 \\
\text { million cubic meters per year. }\end{array}$ \\
\hline Fly ash & $\begin{array}{l}\text { NRG power } \\
\text { station }\end{array}$ & $\begin{array}{l}\text { Cement Australia } \\
\text { Holdings PTY } \\
\text { Ltd }\end{array}$ & $\begin{array}{l}\text { About } 40 \mathrm{kt} / \text { year of fly ash is reused } \\
\text { as cement additive with the re- } \\
\text { maining recovered fly ash is used } \\
\text { outside the region. }\end{array}$ \\
\hline $\begin{array}{l}\text { Spent cell linings or calcined } \\
\text { ash }\end{array}$ & $\begin{array}{l}\text { Boyne Smelters } \\
\text { Ltd }\end{array}$ & $\begin{array}{l}\text { Cement Australia } \\
\text { Holdings PTY } \\
\text { Ltd }\end{array}$ & $\begin{array}{l}\text { About } 12 \mathrm{kt} / \mathrm{year} \text { is reused as alterna- } \\
\text { tive fuel and raw material in clinker } \\
\text { production. }\end{array}$ \\
\hline $\begin{array}{l}\text { Solvent-based fuels from } \\
\text { processing and premixing } \\
\text { different waste solvent } \\
\text { materials }\end{array}$ & $\begin{array}{l}\text { Geocycle Pty Ltd } \\
\text { (part of the } \\
\text { Cement } \\
\text { Australia } \\
\text { Group) }\end{array}$ & $\begin{array}{l}\text { Cement Australia } \\
\text { Holdings PTY } \\
\text { Ltd }\end{array}$ & $\begin{array}{l}\text { Solvent-based fuels are reused as } \\
\text { alternative fuel and raw material in } \\
\text { clinker production. }\end{array}$ \\
\hline $\begin{array}{l}\text { By-product of ammonium } \\
\text { nitrate production }\end{array}$ & Orica & $\begin{array}{l}\text { Agricultural } \\
\text { companies in } \\
\text { Gladstone }\end{array}$ & $\begin{array}{l}\text { By-product of ammonium nitrate } \\
\text { production is used as fertilizer that } \\
\text { is supplied to the agricultural } \\
\text { companies in the region }\end{array}$ \\
\hline
\end{tabular}


opportunities for improvement in the current setup, which can expedite the circularity of those industrial areas.

Moreover, emerging development at the Coolum Eco-Industrial Park along Quanda Road in the Sunshine Coast of Queensland is worth to reckon with on the aspect of eco-industrial area development [18]. The said park is the first industrial park to have received a six-leaf certification from the Urban Development Institute of Australia for eco-efficiency specifically based on the criteria of water efficiency, energy efficiency, ecosystem protection, sustainable community, environmental responsibility and comprehensive waste management [19]. Currently, the Queensland Government through the Sunshine Coast Regional Council continues to promote the positioning of industries in this area for reasons of eco-efficiency and sustainable benefits. So far, Australia has established three working eco-industrial parks to advance circularity among industries across the country; other sustainable paradigms such as that of sustainable mixed communities specifically are either developing (e.g. Logis Eco-Industrial Park) or yet underway (e.g. Victorian Eco-Innovation Lab and Fitzgibbon Chase) or perhaps in the planning stage for effective implementation. The usual or common mechanism in these paradigms of sustainable mixed communities is on water efficiency (e.g. water reticulation) and on designs promoting perfect co-existence with the natural environment $[20,21]$. Such mechanisms are obviously essential to the development of a large-scale circular economy where both production and consumption are clean and sustainable.

\section{Small-Scale Initiatives (Single to Few Industries)}

Corder et al. [22] had introduced waste exchange networks that refer to waste generators being matched with their potential users for waste-based exchanges to occur as shown in Table 3.

Apart from the above initiatives, there have been some fragmented actions taken by individual firms to induce circularity. Food waste, for instance, has been used up by certain industries to boost energy production. Reuse of which is particularly done by treatment plants in South Australia (Glenelg water treatment plant) and Victoria (Aurora sewage treatment plant) [23-25]. On the other hand, Interface, the world's largest designer and maker of carpet tiles, had instituted ReEntry Carpet Tile Recycling that pioneers the carpet recycling program in the world. In its commitment to be a sustainable company, it uses life cycle assessment to be aware of its footprints and is keen to use for its products recycled and bio-based materials with its Mission Zero program. Over the 10-year period, the company had increased to $50 \%$ the use of such materials in its products. It has been working with a poor fishing community for the discarded fishing nets to be recycled in the company's production of carpet tiles through the Net-Works initiative. With consciousness about its footprints, it has collaborated with the Zoological Society of London to help the company re-imagine the value chain it is to work with [26].

Furthermore, a company in Sydney, Australia, is into the business of promoting circularity through upcycling and recycling of waste. Founded in 2001 by Tom Szaky, the company has evolved into a world leader in the recycling and turning "difficult-to-recycle" materials into innovative products from merely a producer of organic fertilizer before. TerraCycle, as it is called today, has more than 100 brands in 21 countries and profits uniquely by designing waste out strategically and wisely. It works with waste streams especially with companies having "non-recyclable" waste. For such matter, TerraCycle finds new commercial uses for this waste type through repurposing strategies. Ingenious ways of upcycling and recycling waste by the company include turning cigarette butts into park benches and waste bins as well as recycling 
Table 3 Waste exchanges in Australia [22]

\begin{tabular}{|c|c|c|c|c|}
\hline Name & Administrating organization & $\begin{array}{l}\text { Year } \\
\text { established }\end{array}$ & Geographic coverage & Activity \\
\hline $\begin{array}{l}\text { Streamline } \\
\text { WasteNot } \\
\text { Resource } \\
\text { Exchange }\end{array}$ & Parramatta City Council (NSW) & 2010 & $\begin{array}{l}\text { Not limited by the } \\
\text { tool, but originally } \\
\text { targeted at Western } \\
\text { Sydney }\end{array}$ & Low since 2011 \\
\hline $\begin{array}{l}\text { City of West } \\
\text { Torrens } \\
\text { Waste } \\
\text { exchange } \\
\text { register }\end{array}$ & $\begin{array}{l}\text { City of West Torrens (South } \\
\text { Australia) }\end{array}$ & 2005 & $\begin{array}{l}\text { City of West Torrens } \\
\text { LGA }\end{array}$ & $\begin{array}{l}\text { No listings in the } \\
\text { past } 2 \text { years }\end{array}$ \\
\hline $\begin{array}{l}\text { WastePro } \\
\text { Waste } \\
\text { exchange } \\
\text { database }\end{array}$ & $\begin{array}{l}\text { WastePro developed by the } \\
\text { Victorian Waste Management } \\
\text { Association (VWMA) with sup- } \\
\text { port from EPA Victoria }\end{array}$ & Unknown & Victoria & $\begin{array}{l}\text { Website no longer } \\
\text { accessible }\end{array}$ \\
\hline $\begin{array}{l}\text { Construction } \\
\text { Connect }\end{array}$ & Construction Connect Australian & Unknown & Australia-wide & $\begin{array}{l}\text { Website no longer } \\
\text { accessible }\end{array}$ \\
\hline $\begin{array}{l}\text { Demolition } \\
\text { Materials } \\
\text { Management } \\
\text { System }\end{array}$ & NA-research demonstration project & 2007 & Australia & $\begin{array}{l}\text { Website no longer } \\
\text { accessible }\end{array}$ \\
\hline $\begin{array}{l}\text { Waste } \\
\text { Exchange }\end{array}$ & Anon. & 2004 & Australia-wide & $\begin{array}{l}\text { Inactive-last } \\
\text { updated in } \\
2006\end{array}$ \\
\hline $\begin{array}{l}\text { The Waste } \\
\text { Exchange } \\
\text { Web Page }\end{array}$ & Anon. & 2003 & Australia-wide & $\begin{array}{l}\text { Inactive (no } \\
\text { listings to be } \\
\text { viewed) }\end{array}$ \\
\hline $\begin{array}{l}\text { Sydney Waste } \\
\text { Exchange }\end{array}$ & Concrete Recyclers (Group) Pty Ltd & 2002 & Sydney & $\begin{array}{l}\text { Standard of web } \\
\text { design suggests } \\
\text { low, if any, } \\
\text { activity }\end{array}$ \\
\hline
\end{tabular}

coffee capsules, cleaner packaging materials (beauty, cleaning and laundry triggers, pumps and dishwasher tabs) and oral care product wastes (i.e. toothpaste tubes, toothbrushes, toothpaste caps and floss containers). In Australia, TerraCycle continues to advance its advocacy on paradigm shifts for businesses to plow back into the markets some innovative products from waste through repurposing, reengineering and redesigning strategies to induce "positive economics" [27].

Circular Economy Australia [28] has also documented a social enterprise whose main activity is 3D printing. Established in 2013, Three Farm has been advocating social and environmental good through 3D printing. It makes use of various initiatives to foster ingenuity, co-creation, sustainability, skills sharing, knowledge and innovation among its partners and associates. These initiatives include Tinkerklass (a workshop for beginners on creating sustainable designs through digital fabrication, CAD/CAM software and 3D printing), Makers Place (focused on digital fabrication and include the benefits of innovative thinking, skilled workforce, improved craftsmanship and provision of a testing facility for the innovation), Open Materials Library (an avenue to be educated about the potential materials to use for the innovation) and Tinkertecture (range of products from up-cycled materials from printing businesses). The enterprise teaches its associates on the principles of circular economy and the value of waste as a resource with the aim of producing both social and environmental good in the process [28]. 
Across Australia, the extended producer responsibility legislation had put 130 liable parties to marshal efforts to undertake upstream recycling activities for television and computer waste, resulting to more than 130,000 tons of metals, leaded and non-leaded glass, plastics and other recyclables to be recycled, and around 6,900 tons of waste off the dumpsite for a cost of A $\$ 50$ 60 million to producers annually [29]. On the other hand, remanufacturing is a strategy that works well for circular economy to evolve and to slowly take effect. Fuji Xerox Australia had done such through its Eco Manufacturing center as part of its extended producer responsibility efforts [30]. The strategy remanufactures about 150,000 parts and subassemblies annually, which provides $30 \%$ of Fuji Xerox Australia's spare parts every year [30]. Remanufacturing is a restoration process for used parts to be available for resale, which comes with some other terms such as refurbished, reconditioned, rebuilt and recertified [31]. The market for remanufactured products is huge with a value of around $\$ 100$ billion per year [31].

In the same vein, metal recycling involving multiple players has also found its way into the stream of circular economy strategies following a more profound contemplation on the capability of Australia to do a mining-led CE. Florin et al. [31] had recorded the initiatives of the metal recyclers to push through their efforts on recycling metals. Two main associations have evolved for this purpose: the Australian Council of Recyclers (ACOR) and the Australian Metal Recycling Industry Association (AMRIA). Metal recycling is most common for steel and titanium. The major players in this industry include Sims Metal Management Limited, Arrium Limited and Sell \& Parker, among others such as CMA Corporation, Pacific Metal Group, Dodd \& Dodd, and P.F. Metals. Although metal recycling has been going on in Australia for years already, much is yet to be done to make it go continuously, especially in keeping the cost down to do it. This is also true to e-waste collection and processing which is undertaken on a business scale by Sims Metal Management Limited, Veolia Environmental Services Pty Limited, Sembsita Australia Pty Ltd and other firms such as Tox Free Solutions Ltd and PGM Refiners [31].

\section{The Driving Force of Circular Economy in Australia}

The widespread implementation of strategies towards closing the loop or controlling the footprints of industries to water, air and land is accounted for by a number of reasons. Concerns on sustainability with the environment under constant pressure from emissions to air, water and land are inevitable, because industry operations are expected to produce such emissions to the environment on a daily basis. Barlow [5] has acknowledged the importance of heeding the call of sustaining environmental health in its report for the sustainability of the agri-food and fiber sector specifically. In sustainability, the country has long been able to recognize that the environment is a key factor. That realization is basically the main driver of today's efforts to put traction on the implementation of circular economy. Two web-based platforms in the country have facilitated the momentum of doing so. The Australian Industrial Ecology Network (AIEN) and the Circular Economy Australia (CEA) are the platforms devoted to advocate the cornerstones of circular economy. Both organizations supplement each other in sorting out concerns particularly in designing waste out through active discussions in their networks.

However, at specific levels, the implementation of $\mathrm{CE}$ in industries has some sets of unique drivers, although these drivers may have similarities with some other industries. The mining industry, for instance, has drivers in the form of economic incentives from increased revenues with reduced cost, risk and liability; information availability; corporate sustainability and 
social responsibility, new entrants to the industry bringing in fresh ideas; existing environmental regulations; technical equipment; and R \& D knowledge updates [17]. In the same vein, Giurco et al. [11] published the drivers for CE as having to do with the innovations that any industry will do to catch up with the need to decouple the environment and economic growth (e.g. demand for sustainable mining practices, recycling for metals and consciousness on environmental certification) besides the response to the increasing cost of waste disposal. Manufacturing, according to Giurco et al. [11], has a strategic role to play in this aspect because it can facilitate in design and makeup the ease of recovering materials for recycling and reuse. Advanced manufacturing is going to make headway with it due to the push from global competitiveness and resource efficiency [11]. In the paper of Golev and Corder [32], economic resilience and environmental resilience are pointed out as drivers in tracking the development of resource synergies wherein efficiency through zero discharge technologies, sustainable energy sources and close loops, and recycling characterizes environmental resilience, and strong competitiveness, growing diversity of industries and reliable supply chains indicate economic resilience.

In Australia, the legislation on extended producer responsibility is already a strong impetus to go circular. It is aimed to implement an environmental management approach aligned to cleaner production as a co-regulatory regime to deal with the recovery of discarded televisions and computer equipment [29]. Although there are deficiencies spotted in the mechanism of enforcing the legislation with firms [29], the will to carry out such legislation is a huge step towards circularity that is quite challenging to develop. On the other hand, supply chain certification schemes are the other drivers where compliance to the requirements usually entail the assurance of eco-friendly production and marketing practices particularly on metals and minerals [31]. Metal leasing is another driver, which is applicable to those metals characterized to have high recovery and high price such as gold, copper and platinum group metals [31]. Florin et al. [31] pointed out that for metal leasing to work, collaboration is important to engage in long-term cooperation and information sharing. In the study of Soo et al. [33] regarding end-of-life vehicle (ELV) recycling, the drivers can be induced with a legislation, advanced technologies and recycling efficiency improvement for the revenue. Overall, Van Beers [34] pointed out business networks, industry champions, government policies and consciousness on the benefits (economic, environmental and social) that can facilitate the development of circular economy on a macro scale in Australia.

\section{The Net Benefits of Circularity for Australia}

As shown in the preceding section, developing a circular economy on a macro scale has already taken off and is an ongoing phenomenon that the country seems committed to fully realize. The progress that it is now having is due to the increasing participation of businesses and other stakeholders in the rigors of configuring and assimilating a variety of strategies to carry out the ultimate purpose of CE towards designing waste out. The benefits of doing so are quite overwhelming and estimation of these benefits has been undertaken to understand what Australia will be getting and gaining in the process. Foremost, Australia would tremendously ease its waste burden with circular economy. Van Beers et al. [17], for example, had shown that the synergies formed in the two eco-industrial areas at Kwinana, Western Australia, and at Gladstone, Queensland, had minimized the waste buildup through reuse and reprocessing. For Gladstone, some details are provided in Table 2. The Kwinana case on the other hand had demonstrated a company's (Alcoa) reuse of gypsum (generated by another company (CSBP) 
and stockpiled with an estimated volume of 1.3 million tons) in huge amounts annually (10,000 tons) for rehabilitation purposes (e.g. plant growth and soil stability) [17]. Such is aside from the reused emissions from plant operation at Kwinana industrial area. The utility synergy at Kwinana shows the exchanges of reused emissions such as superheated steam, demineralized and potable water, and pressurized air. Verve Energy channels its superheated steam and some electricity to Tiwest pigment plant that in return supplies demineralized and potable water and pressurized air to Verve Energy [17].

All other cases presented in the preceding section have helped address the waste issue in Australia through remanufacturing, recycling and reuse options, which could provide stability in product supply [31]. Moreover, valuation of benefits associated with circular economy had been made for South Australia through the collaborative report of Lifecycles, EconSearch, Colby Industries and the Global Change Institute of the University of Queensland in 2017. The report analyzed for the potential benefits of transitioning towards circularizing the economy of South Australia. A move towards a more circular economy wherein the environment and the economic growth are decoupled would earn for the state of South Australia an additional 25,700 fulltime equivalent jobs in 2030. The GHG emission will be reduced as well by $27 \%$ or 7.7 million tons of carbon dioxide equivalents in 2030. All of which can be attained with smart solutions such as producing durable/long-lasting and reusable products, making repair and sharing things as norms, recycling wastes, producing biofuels from biomass to replace fossil fuels as main energy source and producing bio-based materials [35]. Florin et al. [31] estimated for Australia the benefits of circularizing its economy as having a value of AU\$26 billion per year and an overall additional value of AU\$9.3 billion for Australian businesses [31, 36].

\section{Barriers, Lessons Learned and Ways Forward}

Circular economy has a pivotal role in achieving sustainable growth without compromising environmental health. In essence, it fits the strategy for development to be truly sustainable. Australia has already worked out a great deal for it in cooperation with multiple sectors (e.g. academia, transportation, manufacturing and business) that have done their roles in order to attain close-loop operations. Potential benefits have been estimated to rationalize the current efforts in the country towards circularity. In the process, the road to $\mathrm{CE}$ is absolutely not a smooth ride and bumps along the way are quite difficult to overcome. Barriers with respect to what should be needed to work out have apparently slowed down the process of fully integrating, mainstreaming and taking CE to the macro level. These barriers may be different across sectors and levels because of differences in technical requirements and endowments, among others.

In mining, Van Beers et al. [17] identified many barriers to have eco-industrial areas to work perfectly for mining-based industries. These barriers include low price for utility resources and low cost for waste disposal, confidentiality and commercial issues, core business focus (i.e. core business being more profitable but inefficient in processes), distance between companies, intensive process for the approval of by-product reuse and availability of reliable recovery technologies. The lack of long-term consideration of the entire life of a mine and the unstable characteristic of mining projects could have contributed to these barriers and to the slowdown of circular economy for mining, prolonging the regime of "irreversible mineral losses and resource sterilization" in the mining industry [37]. Florin et al. [31] pointed out some other barriers to have something to do with not looking across the entire chain for new opportunities, strong focus on material recycling and lack of data for new investment justification. 
Table 4 Strategic actions for the development of a circular economy [38]

\begin{tabular}{|c|c|}
\hline Strategy & Specific actions \\
\hline Replenish stocks and rethink value & $\begin{array}{l}\text { Establish a regional and national system of: } \\
\text { - Environment accounts_-assess health of stocks } \\
\text { - Waste accounts-identify value available resources } \\
\text { - Productivity target-resources and energy }\end{array}$ \\
\hline Design for renewable energy and resource cycles & $\begin{array}{l}\text { Build on renewable energy transition of } \$ 270 \text { billion } \\
\text { invested globally } \\
\text { - Export responsible minerals } \\
\text { - Cycle resources, reverse logistics } \\
\text { Stewardship: design for recreating } \\
\text { - Build knowledge and information exchange }\end{array}$ \\
\hline $\begin{array}{l}\text { Harness disruptive innovation for production and } \\
\text { consumption } 2.0\end{array}$ & $\begin{array}{l}\text { Australia's niche } \\
\text { - Additive and advanced manufacturing } \\
\text { - Consumption rates for one-planet prosperity } \\
\text { New business models for digital age } \\
\text { - Role of social enterprises and not-for-profit organiza- } \\
\text { tions }\end{array}$ \\
\hline Leverage know-how and networks into new markets & Science and technology to mining (example) \\
\hline
\end{tabular}

However, for the Swanbank area, there were constraints that had to be worked out to start the development of an eco-industrial park, which include narrow industry base, clustering of industries not encouraged in the area, absence of a coordinating body to track and manage the progress towards the development of an eco-industrial area, and absence of a required innovation to carry out activities consistent with industrial ecology or circular economy (i.e. a large-scale industrial ecology) [21]. Technological innovation is important particularly in material recycling, which Australia has to improve further and to couple with favorable policies and pricing for recovered materials to fast track the transition to $\mathrm{CE}$ [33]. On the other hand, Van Beers [34] pointed out three major barriers to which the aforementioned ones may fall under as related to the perception of sustainability not a core business at present, the lack of resources in general (especially on technical, economic, infrastructure) and the preference for the short-term over the long-term benefits. With these, Giurco [38] put forth strategic actions to move forward towards circular economy development, which are focused on rethinking value in replenishing stocks, shifting to renewable energy sources and redesigning resource cycles, harnessing disruptive innovation and leveraging knowledge and networks.

Table 4 exhibits the specific actions towards the focused areas where multiple sectors have to collaborate to achieve circularity. Giurco [38] for the path to CE development recognizes the importance of policy coordination for secondary markets and resource productivity, business innovation for sufficiency and new consumption modes, and research, education and collaboration for impact as major instruments. The ways forward should embed these aspects to reinforce current efforts and to expedite the results of future actions towards circularity in the Australian economy. At that point, indicators of circularity for reference and checking on progress are important to be available and harmonized. Lebre et al. [37] have started working on this for the Australian mining industry, which can be looked into for further improvement. A recent work of Howard et al. [39] in the UK has tackled this, which can be a guide of finalizing the set of indicators towards the establishment of a circular economy in Australia. The details of the said work are shown in Table 5 where the indicators are developed based on the goals and principles of circular economy as formulated by the Ellen MacArthur Foundation. 


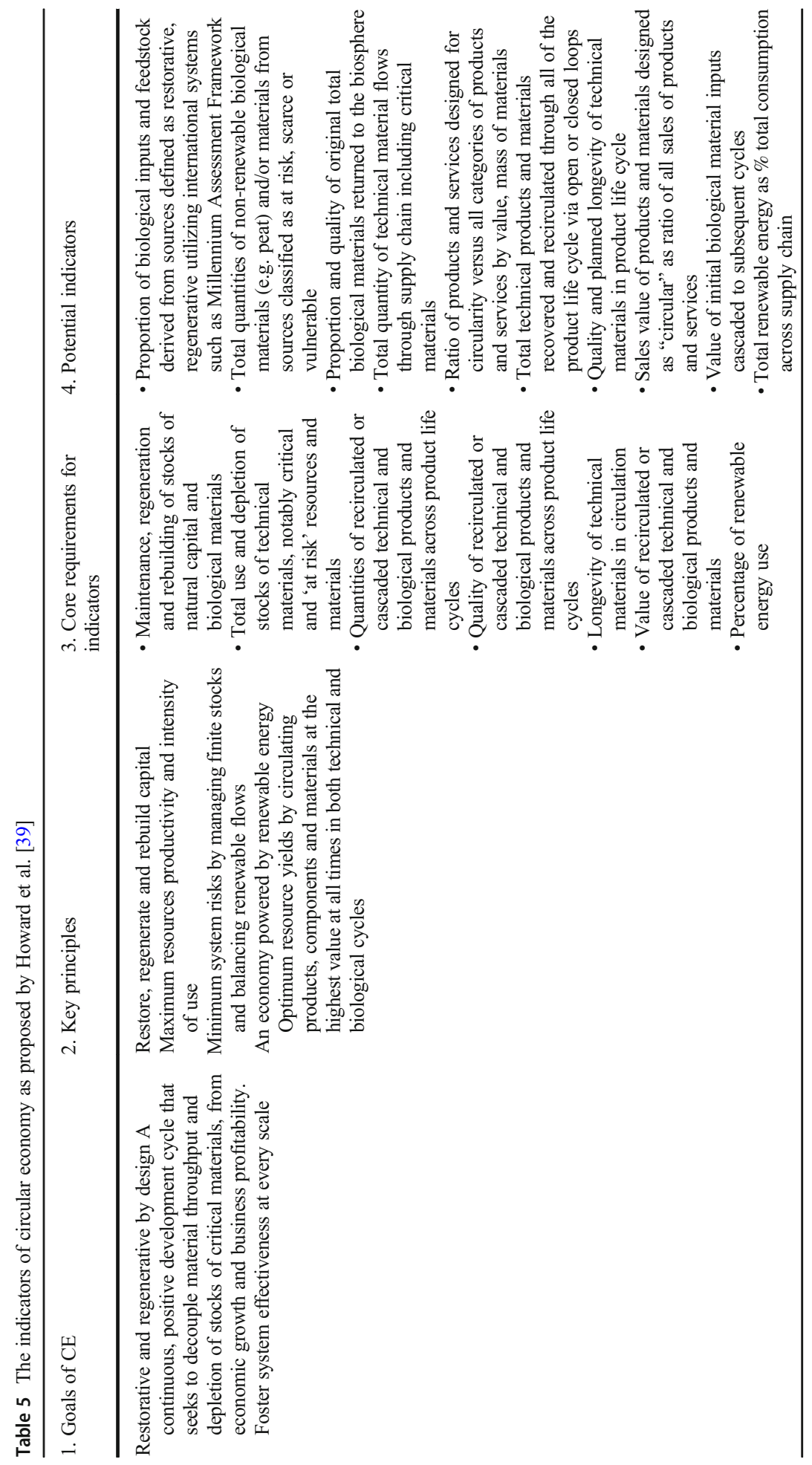




\section{Conclusion}

The efforts of Australia towards seeing circular economy on the ground is impressive. With its motivation to keep externalities and footprints of industrial operations always in check, it has demonstrated its strong willpower to make it happen. The synergies that over time its major industries had developed are commendable in valuing and minimizing waste further, creating the appropriate show windows and opportunities of what eco-efficiency and relentlessly working for sustainable development can result to. Compared to other country advocates of circular economy, it is very close to them in terms of capability to realize circular economy at different levels. Australia's circular economy initiative is quite developed/mature in the industry of mining, in which industrial symbiosis is working in easing up the waste burden besides cutting down cost. It is an appreciable display of an opportunity for responsible mining to be attainable and mining to be sustainable. Many of the efforts associated with $\mathrm{CE}$ in the country as reviewed in this work have tackled at great lengths and diversity in strategies the possibility of making mining sustainable. However, in the aspect of eco-cities, it has to intensify its effort, although plans have been already set.

The participation of industries in the circular economy efforts of Australia has increased over time, resulting to a broader coverage of CE in the country. Mining and manufacturing have led in this aspect and green economies have quite settled in the fact that there are industries that have gone to renewable energy (e.g. solar-powered cars) and recycling on large-scale basis, which demonstrates that overall the country is keen in striking the best balance for economic growth, social development and environmental health to coexist. The said balance is a tall order and difficult to achieve. In fact, even if Australia has done a great deal of efforts already on circular economy, it has not yet been very successful in doing so. As noted, the paper has listed some barriers, not many but tremendous to think about. This just tells that $\mathrm{CE}$ in the country will still take time to fully do its essential functions (e.g. designing out waste, decoupling economic growth and environmental health, waste to wealth creation). The country has yet to look into the ways and mechanism to seamlessly integrate and assimilate its fragmented CE efforts at the moment. The barriers serve the lessons and directions on what to work on seriously, in which very pressing is the agility of the country to respond quickly to the demand for technological innovations in CE.

For it to work to such direction and to see possibly circular economy in full, the synergies of many sectors need to be strengthened and broadened because a macro scale operation of $\mathrm{CE}$ gives a fulfilling outcome. The academia and R \& D institutions would have to increase in number and collaborations to meet the rising demand for technological complements for $\mathrm{CE}$, in which more industries should partake to meet the economical scale of operating CE. Very important for this aspect is on how to take care of co-dependency that through industrial symbiosis many industries have come to develop. The industries should be able to have a kind of partnership that is open and responsive to change altogether to avoid any problem with trust issues. Industrial symbiosis is glued with trust; thus, there should be mechanisms that would foster strengthening trust. The government has a critical role in this aspect because it formalizes the flows, relationships, institutions and feedback loops through guidelines and policies. Policies can help hold together the existing relationships and feedback loops. It is important that the government can look into the relevant policies to strengthen properly the current initiatives for the establishment of CE across Australia and to set some metrics for determining the progress of these initiatives turned into a cohesive whole for sustainable waste-to-wealth creation. Indicators are important to be clear for these metrics to be definite about the progress of efforts towards circularity. It is recommended to look at the work of 
Lebre et al. [37] to check on what needs to be done for this aspect. Thresholds and levels of assimilation of the fragmented circularity efforts are important details to be included in the development of indicators of circularity and/or circular economy in Australia.

\begin{abstract}
Author's Contribution All authors have significantly contributed to the article. Anthony Halog is the leader of the research group and the main supervisor who gives the final approval of what to be published. He has conceptualized the project, given guidance and critical revisions of the article. Raquel Balanay was a former postdoctoral research fellow in the Research Group for Industrial Ecology at UQ who conducted a literature review and drafted the manuscript. Sandra Anieke is former Graduate Student who conducted a systematic review, analyzed the data and drafted the manuscript as part of her MS research project. Tsz Yan Yu is a former Undergraduate Honors Student at UQ who partly contributed in drafting and editing the manuscript.
\end{abstract}

Funding This study was financed in part by the School of Earth and Environmental Sciences at the University of Queensland (UQ), Australia.

\title{
Declarations
}

Consent for Publication We also provide our consent to publish the relevant data and results.

Conflict of Interest The authors declare no conflict of interest.

\section{References}

1. Fowosire RA, Idris OY, Elijah O (2017) Technopreneurship: a view of technology, innovations and entrepreneurship. Global J Res Eng Electric Eng 17(7)

2. Poppelaars, F. (2014), "Designing for a circular economy: the conceptual design of a circular mobile device", accessed 15 November 2018 at https:/www.ellenmacarthurfoundation.org/assets/downloads/ Floras-CEIP-report-Designing-for-a-Circular-Economy.pdf.

3. RSA-Action and Research Centre (2016), "Designing for a circular economy: lessons from the great recovery 2012-2016", accessed 14 November 2018 at https://www.thersa.org/.../the-great-recoverydesigning-for-a-circular-economy.pdf.

4. Australian Department of Industry, Innovation and Science (2016), Advanced manufacturing, accessed 10 December 2018 at https://industry.gov.au/industry/IndustrySectors/Advanced -Manufacturing/Pages/default.aspx.

5. Barlow, Snow (2014), Food and fiber: Australia's opportunities. Australian Academy of Technological Sciences and Engineering, Level 1/1 Bowen Crescent, Melbourne, Victoria 3004 Australia.

6. KPMG (2020). Potential economic pay-off of a circular economy. Available at <https://assets.kpmg/ content/dam/kpmg/au/pdf/2020/potentialeconomic-pay-off-circular-economy-australia-2020.pdf>

7. Circularity Gap Report, (2020). The world is now $8.6 \%$ circular. Available at $<$ https://www.circularitygap.world/2020 >

8. Levitzke PSMV (2020) The development of a circular economy in Australia. Circular Economy, Global Perspective, Springer, pp 25-42

9. DAWE (2018). 2018 National Waste Policy: less waste, more resources. Available at < https://www. environment.gov.au/protection/waste/publications/national-waste-policy-2018 >

10. DAWE, (2017). National food waste strategy. Available at < National Food Waste Strategy $\mid$ Department of Agriculture, Water and the Environment >

11. Giurco D, Littleboy A, Boyle T, Fyfe J, White S (2014) Circular economy: questions for responsible minerals, additive manufacturing and recycling of metals. Resources 3:432-453

12. Golev A, Corder GD (2016) Typology of options for metal recycling: Australia's perspective. Resources 5(1)

13. Golev A, Corder GD (2017) Quantifying metal values in e-waste in Australia: the value chain perspective. Miner Eng 107:81-87

14. Gumley W (2014) An analysis of regulatory strategies for recycling and re-use of metals in Australia. Resources 3(2):395-415

15. ACE Hub, (2020). Strategic action plan 2020-23. Available at < https://assets.ctfassets.net/fajwh0badmlx/ 46fuilIwjt8NosSFzILqdN/8f5eb8039f0a14ac5b79f82485003b75/ACEHUB_3YR_STRATEGIC_ ACTION_PLAN_2020.pdf > 
16. Golev A, Corder GD, Giurco DP (2013) Industrial symbiosis in Gladstone: a decade of progress and future development. J Clean Prod 84:421-429

17. Van Beers D, Corder G, Bossilkov A, Van Berkel R (2007) Industrial symbiosis in the Australian minerals industry. J Ind Ecol 11:55-72

18. EnviroDevelopment (undated), Coolum eco industrial park (stage 1), accessed 14 November 2018 at https://www.envirodevelopment.com.au/_bade_upl/Coolum_Industrial_Estate_Case_Study1.pdf.

19. Economic Development Queensland (2016), About Coolum eco industrial park, accessed 14 November 2018 at https://www.ceip.com.au/?name=About-CEIP.

20. PIA (2017), "From plan to place: Logis eco-industrial park", accessed 15 November 2018 at https://www. alexanderurbanism.com/uploads/3/4/4/9/34491523/pia_from_plan_to_place_logis_nomination_statement.pdf.

21. Baumann, C., Asker, S., Giurco, D., Peterseim, J. and S. White (2012), "Eco-industrial transition" a vision for economic and socio-ecological renewal at Swanbank," prepared for Thiess Services by the Institute for Sustainable Futures, University of Technology, Sydney, Australia.

22. Corder GD, Golev A, Fyfe J, King S (2014) The status of industrial ecology in Australia: barriers and enablers. Resources 3:340-361

23. Jacobs (2015), "A bio-energy roadmap for South Australia. Renewables SA-Jacobs Report”, accessed 15 November 2018 at http://www.renewablessa.sa.gov.au/content/uploads/2018/03/a-bioenergy-roadmap-forsouth-australia-report-version-1.pdf.

24. Green Industries South Australia (2017), "Benefits of a circular economy in South Australia", accessed 14 November 2018 at https://www.greenindustries.sa.gov.au/_literature_172176/Benefits_of_a_Circular Economy_in_South_Australia_-_summary_(2017).

25. Australian Water $\overline{\text { Association, }} \overline{2}$ 2016. Victoria launches new grants for waste to energy, accessed 10 December 2018 at http://www.awa.asn.au/AWA_MBRR/Publications/Latest_News/Victoria_launches new_grants_for_waste-to-energy.aspx.

26. Circular Economy Australia (2015), Interface, accessed 14 November 2018 at https://static1.squarespace. com/static/5373f9e1e4b07d0c6bf25a9f/t/5567cd93e4b07c004ad65c92/1432866195850/Interface Working_15thMay2015.pdf.

27. Circular Economy Australia (undated), Terracycle, accessed 14 November 2018 at https://static1. squarespace.com/static/5373f9e1e4b07d0c6bf25a9f/t/553094cfe4b086967b6dcc6d/1429247194189/ TerraCycle+Deviate2Innovate.pdf.

28. Circular Economy Australia (undated), Three Farm, accessed 14 November 2018 at https://static1. squarespace.com/static/5373f9e1e4b07d0c6bf25a9f/t/5656481be4b09e2585402140/1448495131178/ ThreeFarm Working 30thApril2015.pdf.

29. Lodhia S, Martin N, Rice J (2017) Extended producer responsibility for waste televisions and computers: a regulatory evaluation of the Australian experience. J Clean Prod 164:927-938

30. Florin N, Dominish E, Giurco D (2015) Action Agenda for resource productivity and innovation: opportunities for Australia in the circular economy. University of Technology, Sydney

31. Florin N, Madden B, Sharpe S, Benn S, Agarwal R, Perey R, Giurco D (2015) Shifting business models for a circular economy: metals management for multi-product-use cycles. UTS, Sydney

32. Golev A, Corder GD (2011) Developing a classification system for regional resource synergies. Miner Eng 29:58-64

33. Soo VK, Peters J, Compston P, Doolan M, Duflou JR (2017) Comparative study of end-of-life vehicle recycling in Australia and Belgium. Procedia CIRP 61:269-274

34. Van Beers, D. (2015), "International perspectives and learnings for Australia and Asia-Pacific", paper presented at the WRF Workshop: Industrial Symbiosis, 1 June 2015, Sydney.

35. Lifecycles, EconSearch, Colby Industries, University of Queensland: Global Change Institute (2017), "Creating value: the potential benefits of a circular economy in South Australia", accessed 15 November 2018 at https://www.greenindustries.sa.gov.au/_literature_172204/Potential_Benefits_of_a_Circular_ Economy_in_South_Australia_-_report_(2017).

36. White, M. (2015), "Circular economy to become \$26bn industry in Australia by 2025: World Economic Forum”, The Sydney Morning Herald, accessed 15 November at https://www.smh.com.au/national/circulareconomy-to-become-26bn-industry-in-australia-by-2025-world-economic-forum-20150630-gi19n3.html.

37. Lébre E, Corder G, Golev A (2017) The role of the mining industry in a circular economy. J Ind Ecol 0:1-11

38. Giurco, D. (2015), "Resource productivity and innovation, action agenda for the circular economy", paper presented at the World Resources Forum Asia Pacific, 2 June 2015, Sydney.

39. Howard M, Hopkinson P, Miemczyk J (2018) The regenerative supply chain: a framework for developing circular economy indicators. Int J Prod Res 57:7300-7318. https://doi.org/10.1080/00207543.2018. 1524166 